\title{
Growth of rats given cod-liver oil
}

\author{
BY R. J. WARD* AND CATHERINE C. AMOS \\ British Cod Liver Oils (Hull and Grimsby) Ltd, Hull
}

(Received 21 September I96I-Revised 4 December 196I)

Ershoff (1960) reported recently that immature rats of the Holtzman strain given a purified diet supplemented with tunny, sardine, menhaden or cod-liver oil showed a highly significant retardation in growth which was evident during the Ist week of feeding. In this period there was an almost complete cessation of body-weight increase or even a loss in body-weight, accompanied by diarrhoea. In contrast, the addition of $10 \%$ of cottonseed oil to the diet containing the fish oil or the addition of certain antioxidants to the fish oils counteracted the growth-retarding effect and the diarrhoea. It is of interest to note that in the issue of the journal containing Ershoff's paper Privett, Pusch, Holman \& Lundberg ( 1960 ) reported that the addition of $10 \%$ menhaden, tunny or herring oil to the diet of rats caused a weight increase similar to that caused by 10\% maize oil.

In experiments conducted at the biological testing station of our Company, rats given a different basal diet, which, however, contained a similar amount of cod-liver oil, have shown no depression of weight increase or diarrhoea. It therefore seemed important to repeat the experiments described by Ershoff under conditions as nearly identical to his as possible.

\section{EXPERIMENTAL}

Groups of three male and three female rats of the Wistar albino strain were given the basal low-fat diet or the basal low-fat diet to which had been added Io $\%$ cod-liver oil $\mathrm{BP}$ in place of an equivalent weight of sugar. Other groups received the basal diet with $10 \%$ cod-liver oil to which had been added $0.05 \% \alpha$-tocopherol, $0.05 \% 6$-ethoxy2,2,4-trimethyl-1,2-dihydroquinoline (Santoquin, Monsanto), 0.05\% 2,6-di-t-butyl4-methyl phenol (BHT) or $0.02 \%$ mono-t-butyl quinol (MBQ). A further group received the basal low-fat diet with $10 \%$ cod-liver oil that had been aerated at $60^{\circ}$ to increase the initial peroxide value of 5 to about 20. As a positive control, another group received the basal low-fat diet with $10 \%$ cottonseed oil. The composition of the diets is given in Table $\mathbf{I}$.

The rats were weighed twice weekly and careful observation was kept for signs of diarrhoea.

\section{RESULTS}

The mean gains in body-weight after $8, \mathrm{I}_{5}, 22$ and 29 days for the eight groups are given in Table 2.

The addition of cod-liver oil to the basal low-fat diet had little effect on the gain in

* Present address: Reckitt and Sons Ltd, Hull. 


\section{Table I. Percentage composition of diets}

$\begin{array}{cc}\text { Basal } & \text { Basal } \\ \text { low-fat } & \text { low-fat oil }\end{array}$

$\begin{array}{lrr}\text { Sugar } & 7 \mathrm{I} & 6 \mathrm{I} \\ \text { Casein (vitamin-free) } & 24 & 24 \\ \text { Salt mixture* } & 5 & 5 \\ \text { Oil } & 0 & \text { IO } \\ \text { Vitamins } & \dagger & +\end{array}$

* Composition of salt mixture (parts)

Sodium chloride

Calcium phosphate $\left(\mathrm{Ca}_{3}\left(\mathrm{PO}_{4}\right)_{2}\right)$

Ferric citrate $\left(\mathrm{FeC}_{6} \mathrm{H}_{5} \mathrm{O}_{7} \cdot 5 \mathrm{H}_{2} \mathrm{O}\right)$

Potassium iodide

Magnesium sulphate $\left(\mathrm{MgSO}_{4} \cdot{ }_{7} \mathrm{H}_{2} \mathrm{O}\right)$

$\begin{array}{rlc}50 & \text { Sodium acid phosphate }\left(\mathrm{NaH}_{2} \mathrm{PO}_{4} \cdot{ }_{2} \mathrm{H}_{2} \mathrm{O}\right) & 150 \\ 400 & \text { Potassium chloride } & 250 \\ 35 & \text { Sodium fluoride } & 0.04 \\ \text { I } & \text { Manganese sulphate }\left(\mathrm{MnSO}_{4} \cdot 4 \mathrm{H}_{2} \mathrm{O}\right) & 0.2 \\ 80 & & \end{array}$

† Vitamins added per $\mathrm{kg}$ diet

Thiamine hydrochloride (mg)

Riboflavin hydrochloride (mg)

Pyridoxine hydrochloride (mg)

Calcium pantothenate (mg)

Nicotinic acid (mg)

Ascorbic acid (mg)

Biotin (mg)

Folic acid $(\mathrm{mg})$

$\begin{array}{rl}20 & p \text {-Aminobenzoic acid (mg) } \\ 20 & \text { Inositol (mg) } \\ 20 & 2 \text {-Methyl-I,4-naphthaquinone }(\mathrm{mg}) \\ 60 & \text { Vitamin } \mathrm{B}_{12}(\mu \mathrm{g}) \\ 100 & \text { Choline chloride (g) } \\ 200 & \text { Vitamin A (i.u.) } \\ 4 & \text { Vitamin D (i.u.) } \\ 10 & \alpha \text {-Tocopheryl acetate (mg) }\end{array}$

400

800

Table 2. Effect on weight gain of rats of various supplements added to the basal low-fat diet

(Groups of three male and three female rats of mean initial body-weight $52 \pm \mathrm{I}_{4} 4$ and $5 \mathrm{I} \pm \mathrm{I} \cdot 3 \mathrm{~g}$, respectively)

\begin{tabular}{|c|c|c|c|c|c|}
\hline \multirow[b]{2}{*}{ Supplement } & \multirow{2}{*}{$\begin{array}{l}\text { Sex } \\
\text { of } \\
\text { rats }\end{array}$} & \multicolumn{4}{|c|}{$\begin{array}{l}\text { Mean gain in body-weight }(\mathrm{g}) \\
\text { after days of feeding }\end{array}$} \\
\hline & & 8 & 15 & 22 & $29^{*}$ \\
\hline None & $\begin{array}{l}x \\
0 \\
9\end{array}$ & $\begin{array}{l}27 \\
27\end{array}$ & $\begin{array}{l}58 \\
44\end{array}$ & $\begin{array}{l}99 \\
6 \mathbf{I}\end{array}$ & $\begin{array}{r}129 \pm 0.8 \\
76 \pm 5.5\end{array}$ \\
\hline 10\% cod-liver oil B.P. & $\begin{array}{l}\hat{O} \\
\dot{T}\end{array}$ & $\begin{array}{l}30 \\
29\end{array}$ & $\begin{array}{l}60 \\
49\end{array}$ & $\begin{array}{l}94 \\
61\end{array}$ & $\begin{array}{r}127 \pm 7 \cdot 5 \\
81 \pm 4 \cdot 0\end{array}$ \\
\hline ı $\%$ cod-liver oil (peroxide value $=20$ ) & $\begin{array}{l}\pi \\
o \\
0\end{array}$ & $\begin{array}{l}29 \\
26\end{array}$ & $\begin{array}{l}53 \\
44\end{array}$ & $\begin{array}{l}90 \\
63\end{array}$ & $\begin{array}{r}\operatorname{II} \pm 6 \cdot 8 \\
82 \pm I \cdot 7\end{array}$ \\
\hline ro $\%$ cod-liver oil $+0.05 \%$ a-tocopherol & $\begin{array}{l}\hat{\delta} \\
\stackrel{1}{q}\end{array}$ & $\begin{array}{l}28 \\
27\end{array}$ & $\begin{array}{l}64 \\
49\end{array}$ & $\begin{array}{l}95 \\
64\end{array}$ & $\begin{array}{r}\text { I I } 2 \pm 8 \cdot 8 \\
84 \pm 5 \cdot 8\end{array}$ \\
\hline ro $\%$ cod-liver oil $+0.05 \%$ Santoquin & $\begin{array}{l}x \\
0 \\
0\end{array}$ & $\begin{array}{l}34 \\
27\end{array}$ & $\begin{array}{l}65 \\
49\end{array}$ & $\begin{array}{l}97 \\
60\end{array}$ & $\begin{array}{r}13 \pm \pm 5 \cdot 8 \\
82 \pm 3 \cdot 3\end{array}$ \\
\hline I0 $\%$ cod-liver oil to.05\% BHT & $\begin{array}{l}3 \\
9 \\
9\end{array}$ & $\begin{array}{l}34 \\
24\end{array}$ & $\begin{array}{l}62 \\
44\end{array}$ & $\begin{array}{l}96 \\
65\end{array}$ & $\begin{array}{r}131 \pm 6 \cdot 5 \\
85 \pm x \cdot 6\end{array}$ \\
\hline ro $\%$ cod-liver oil $+0.02 \% \mathrm{MBQ}$ & $\begin{array}{l}\hat{o} \\
0 \\
0\end{array}$ & $\begin{array}{l}28 \\
33\end{array}$ & $\begin{array}{l}57 \\
54\end{array}$ & $\begin{array}{l}89 \\
72\end{array}$ & $\begin{array}{r}\text { I } 20 \pm 5.8 \\
85 \pm 8 \cdot 4\end{array}$ \\
\hline Io $\%$ cottonseed oil & $\begin{array}{l}3 \\
0 \\
0\end{array}$ & $\begin{array}{l}32 \\
27\end{array}$ & $\begin{array}{l}63 \\
43\end{array}$ & $\begin{array}{l}96 \\
59\end{array}$ & $\begin{array}{r}117 \pm 5 \cdot 5 \\
78 \pm 2 \cdot 8\end{array}$ \\
\hline
\end{tabular}

BHT, 2,6-di-t-butyl-4-methyl phenol; MBQ, mono-t-butyl quinol.

* With its standard error. 
weight of either the males or females. The addition of antioxidants to the cod-liver oil did not improve the gain, and increase in peroxide value also had little effect on it. The addition of cottonseed oil to the basal low-fat diet did not cause any increased gain in body-weight.

No diarrhoea was observed in any of the animals.

\section{DISCUSSION}

Contrary to the report by Ershoff ( 1960 ), the addition of cod-liver oil caused neither a retardation in weight increase nor diarrhoea over the 29 days of the experiment. The gain in weight of the males receiving the basal low-fat diet was similar to that reported by Ershoff, 27, 58, 99 and $129 \mathrm{~g}$ for the 8th, $15^{\text {th }}$, 22nd and $29^{\text {th }}$ days of feeding, compared with $27,64,93$ and $124 \mathrm{~g}$ for the 7 th, 14 th, 2 ist and 28 th days of feeding. It was not unexpected that the addition of antioxidants to the cod-liver oil had little or no effect on the rate of weight gain. Two of the antioxidants used in this experiment were not used by Ershoff. BHT was chosen because it is a permitted antioxidant under the Antioxidant in Food Regulations, 1958 (Great Britain: Parliament, I958), and MBQ has been shown by Lea (1960) to have exceptional in vitro antioxidant properties when used with cod-liver oil esters. Similarly K. De Witt (r96r, personal communication) has shown that MBQ at a level of $0.00 \mathrm{r} \%$ was as effective as $\mathrm{BHT}$ at $0.02 \%$ in preventing peroxide formation when cod-liver oil was gently shaken in air at room temperature. It is unfortunate that no studies appear to have been made on the toxicity of MBQ. In a preliminary experiment, Ward \& Amos (I96r, unpublished) have shown that MBQ at a level of $2 \%$ (Ioo times the permitted level of antioxidants) caused a significant decrease in weight gain, which appeared to be greater in males than in females.

It was expected that the cod-liver oil with the increased peroxide value would cause a decrease in the weight gain, and possibly diarrhoea, but it did not within the experimental period. T. Moore ( $196 \mathrm{r}$, personal communication) has observed diarrhoea in rats given highly oxidized cod-liver oil. Unfortunately no details are given by Ershoff about the peroxide values of the oils he used, but it is difficult to believe that a codliver oil with a peroxide value greater than 20 would have been used for a nutritional experiment. It is, therefore, difficult to account for the decreased rate of weight gain and diarrhoea observed by him, with the possible unlikely explanation that rats of the Holtzman strain are particularly sensitive to cod-liver oil.

\section{SUMMARY}

I. The effects of cod-liver oil, when added to a basal low-fat synthetic diet have been studied in male and female weanling rats.

2. Contrary to previous reports, there was no decrease in rate of weight gain, or diarrhoea.

3. The rate of weight gain of the rats over a short experimental period was influenced neither by artificially increasing the peroxide value of the cod-liver oil nor by adding antioxidants to it. 
We wish to thank the Directors of British Cod Liver Oils (Hull and Grimsby) Ltd, for permission to publish this paper, and Miss J. Watson and Miss B. Cowell for caring for the animals used in the work.

\section{REFERENCES}

Ershoff, B. H. (1960). F. Nutr. 7r, 45 .

Great Britain: Parliament (1958). Antioxidant in Food Regulations, 1958. Stat. Instrum. no. 1454 Lea, C. H. (1960). F. Sci. Fd Agric. II, I43.

Privett, O. S., Pusch, F. J., Holman, R. T. \& Lundberg, W. O. (1960). F. Nutr. 71, 66. 